\title{
Botanical biopesticide combination concept-a viable option for pest management in organic farming
}

\author{
D. Srinivas Reddy ${ }^{1 *}$ and N. Mounica Chowdary ${ }^{2}$
}

\begin{abstract}
Background: Entomopathogens are frequent natural enemies of arthropods worldwide, and they are capable of alternative control agents against the important pests. The optimally selected botanical product can minimize their harmful effect on these entomopathogens, and it becomes essential to know the influence of combinations of botanicals and biopesticides (botanical biopesticide combination (BBC)) in comparison to their sole action.

Main body: Botanicals, especially neem products, are highly efficient to be combined with the entomopathogens (with some exceptions). There are many possible reasons for the synergistic action of these botanicals, attacking the immune system of the insect being one of the important ones. These botanicals when applied in combination with microbial pesticides showed maximum sublethal effects rather than complete mortality, making them the best alternatives for combating resistance development in insects. To work effectively, biological control agents must be used within a compatible program combined with botanicals. It is highly difficult for such products to compete with chemical controls in high-value crops, so where they can become a commercially viable option in organic cultivation. The increasing acreage is under organic production for high-value export crops, where pesticide residues are undesirable for the environment, and biopesticides and botanicals are good choices for crop protection. Concerning the effect of these products used in pest control, a significant reduction in dosage in relation to the individuals is noticed.

Conclusion: By combining the performance and safety, biopesticides and botanicals are efficacious. This knowledge should facilitate the choice of biopesticides compatible with less harmful or naturally occurring botanicals. And if these have to be incorporated into a pest management program through an organic approach, it is necessary to determine the effects of botanicals on the beneficial microbes, on the behavior of pest, the importance of application technique, and the role of application timing for these botanical biopesticide combinations.
\end{abstract}

Keywords: Entomopathogens, Botanicals, Synergism, Combinations, Neem, Organic agriculture

\footnotetext{
* Correspondence: dsr2020@gmail.com

'AICRP on Fruits, Citrus Research Station, Drysrhu, Tirupati, Andhra Pradesh

517501, India

Full list of author information is available at the end of the article
}

\section{Springer Open}

(c) The Author(s). 2021 Open Access This article is licensed under a Creative Commons Attribution 4.0 International License, which permits use, sharing, adaptation, distribution and reproduction in any medium or format, as long as you give appropriate credit to the original author(s) and the source, provide a link to the Creative Commons licence, and indicate if changes were made. The images or other third party material in this article are included in the article's Creative Commons licence, unless indicated otherwise in a credit line to the material. If material is not included in the article's Creative Commons licence and your intended use is not permitted by statutory regulation or exceeds the permitted use, you will need to obtain permission directly from the copyright holder. To view a copy of this licence, visit http://creativecommons.org/licenses/by/4.0/. 


\section{Background}

The use of toxic chemicals for pest management has created many unwanted effects. The greatest problem is due to the residues of chemical insecticides and the development of resistance to these by the pests. Constant innovations are the only way to achieve success in the field of agriculture to cope with these biotic stresses. Due to the continuous evolution of these organisms leading to pesticide resistance, a continuous parallel research is needed to check them.

Since the 1800s, the wide-spread and increasing trend of chemical insecticide usage leading to many environmental imbalances and human health hazards. Farmers need to be switched to more effective and environmentally sustainable solutions of crop protection. Chemicals may be a dominant market today, but the fastest growing biological inputs are the future. The biological method provides the best alternative in maintaining the insect populations in balance without causing harm to other organisms and beneficial fauna in the ecosystem (Lv et al. 2011). In addition, bringing a chemical pesticide into the market needs a tiresome process with lots of effort and time, but the biopesticides can be commercialized in a year or so providing a good opportunity to fill the pest management gap created by chemicals.

\section{Main text}

Among the biological methods, botanicals play a major role as they are easily and locally available, and having ease of manufacture, they provide employment at the rural level. Botanicals had been used since the Vedic period for pest control (Koul and Walia 2009). Over three lakh plant species are estimated to have pesticidal properties but only 2400 species have been identified and still a lot more to be exploited (Thacker 2002). Only $10 \%$ of the compounds present in the array of plant chemicals are identified, indicating a huge future scope for research. Among these botanicals, neem is the top scorer because of its insecticidal compound, azadirachtin, and the limonoids present that are insecticidal to over 250 agricultural pest species (Morgan 2009). Researchers proved that neem (oil) is as effective as cypermethrin in controlling the tomato fruit borer, Helicoverpa armigera (Hb.) on tomato (Phukon et al. 2014). Neem products can be readily combined with many other bioagents including microbes (Mohan et al. 2007). Even eucalyptus contains many terpenoids like $\alpha$ and $\beta$ pinene, 1,8-cineole (CIN), terpineol, and globulol (Lucia et al. 2012), which are found to have antifungal, antimicrobial, and insecticidal activities (both contact and fumigant) against many pests (Mann and Kaufman 2012). A number of other plants, namely Derris elliptica, Nicotiana tabacum, and Acorus calamus (Wongtang and Nawanich 2001), and medicinal plants viz., Euphorbia sp., Dodone avescosa, and Chinus tribinlitolia (Isman 2006), were found to have insecticidal properties.

Fungi with entomopathogenic effect can be readily incorporated in IPM tactics (Reddy et al. 2013) and more than 750 fungi from over 90 species are being entomopathogenic in nature (Zare and Gams 2001). They are the main pathogens of insects, causing about $80 \%$ of insect diseases (Alves et al. 2008). They enter through the integument and can infect all stages of insects, and if favorable conditions occur, they can create disease outbreaks in insects, especially Hemiptera, Coleoptera, and Lepidoptera (Shubakov and Kucheryavykh 2004). Beauveria, Metarhizium, Verticilium, Nomurea, Aschersonia, Hirsutella, and Entomophthora are those among commercially available genera (Alves et al. 2008). In the total number of entomopathogenic fungi (EPF) formulations developed worldwide, $M$. anisopliae and B. bassiana both share $33.9 \%$ each, followed by Verticilium spp. (9.4\%), Isaria fumosorosea (5.8\%), and B. brongniartii (4.1\%). Among the type of formulations, substrates colonized by fungi are mostly available ( $26 \%$ of total formulation), and others include wettable powders (20.5\%) and oil-dispersions (15.2\%) (Etheimine et al. 2013). Entomopathogenic bacteria are the other most successful microbes after fungi used in pest control where particularly Bacillus thuringiensis (Bt) plays a king role with $2 \%$ of the insecticidal market (Bravo et al. 2011). The baculoviruses (nuclear polyhedral virus and granulosis virus) are one among insecticidal viruses pathogenic to insects, and they are specific to Lepidoptera and Diptera. They are successfully used in the management of universal pests like Helicoverpa sp. and Spodoptera sp. in different parts of the world (Rosell et al. 2008).

A couple of major exploited genera of entomopathogenic nematodes are Steinernema and Heterorhabditis (Sharifi et al. 2014), hosting Xenorhabdus and Photorhabus, symbiotic bacteria, respectively, which are the primary cause for insect mortality within 24-72 h (Adams and Nguyen 2002). These two genera are capable of controlling a wide variety of insect pests of agriculture and forestry (Kulkarni et al. 2017; Paunikar and Kulkarni 2019a, 2019b, 2019c). The only drawback with these microbes is that they are slow in action, and the problem can be tackled by incorporating them with other chemicals in different strategies. Recent approaches proved that "dual-attack" approach can result in a higher mortality of pest than their individual effect. The mixtures of two products are often more effective, showing the effect more their $1+1$ effect, which is technically called synergism. Antagonism is precisely an opposite phenomenon in which the toxicity of two compounds is applied together is less than the expected sum of two individual effects. The less-discussed phenomenon is that antagonism is also likely to occur but mostly masked by positive 
effects produced. Synergy and antagonism are indicated by many terms like co-toxicity coefficient, synergistic ratio, percent mortality, and many sublethal effects on pests reducing the yield loss. The combination of a botanical or a plant extract with insecticidal activity and an entomopathogen is a novel approach to fight against the resistances and resurgence issues created by insect pests (Srivastava et al. 2011). These botanical biopesticide combinations $(\mathrm{BBC})$ are a boon to organic agriculture, resulting in an effective management, not less than a synthetic insecticide.

\section{Synergism between botanicals and entomopathogenic bacteria}

The early research on synergism reported that $B t$ when applied sequentially (Devi et al. 1996) or in combination (Trisyono and Whalon 1999) with neem products showed synergism against different agricultural pests. Synergistic results obtained in studies conducted at CRS,
Tirupati are shown in Fig. 1. Btk (Bt var kurstaki Serotype $\mathrm{H}-3 \mathrm{a}, 3 \mathrm{~b} ; 3000 \mathrm{IU} / \mathrm{mg}, 9 \times 10^{9}$ viable spores/g, 5-8\% endotoxin) and neem seed kernel extract (NSKE, when applied after 2 days of $B t$ spray) against Achaea janata (Linnaeus) on castor produced the highest yield, and the maximum mortality rate was also observed by $B t(0.25 \%)$ + NSKE (2\%), where feeding cessation was observed immediately but mortality was not immediate after spray (Devi et al. 1996). Similarly, the commercial product of $B t$, Delfin ${ }^{\circ}$, was synergistic with neem extract but not with others, Spicturin ${ }^{\circ}$ and Agree ${ }^{\circ}$, and probably the action is due to additives in the former formulation. Even the sublethal concentrations of neem $(0.25-0.45 \mathrm{mg}$ a.i/ $\mathrm{L})$ combined with $B t(0.74 \mathrm{mg}$ a.i $/ \mathrm{L})$ showed an additive effect on larval mortality of Colorado potato beetle, Leptinotarsa decimlineata (Trisyono and Whalon 1999).

The synergistic effects of neem products on $B t k$ were proved by many research (Togbe et al. 2014; Konecka et al. 2019). The $\mathrm{LC}_{50}$ of $B t$ and azadirachtin (Singh et al.
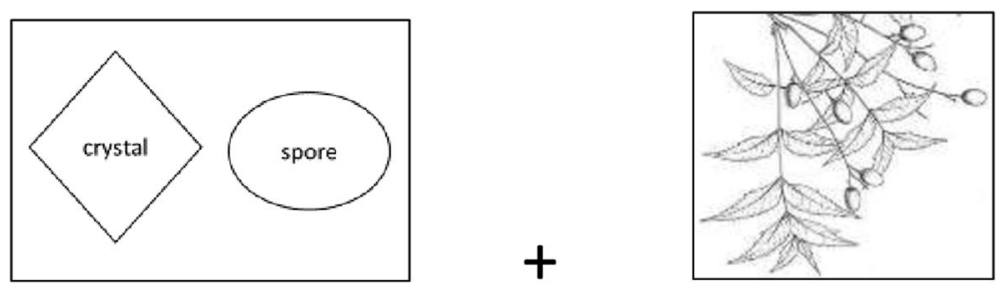

Bacillus thuringinesis

Neem
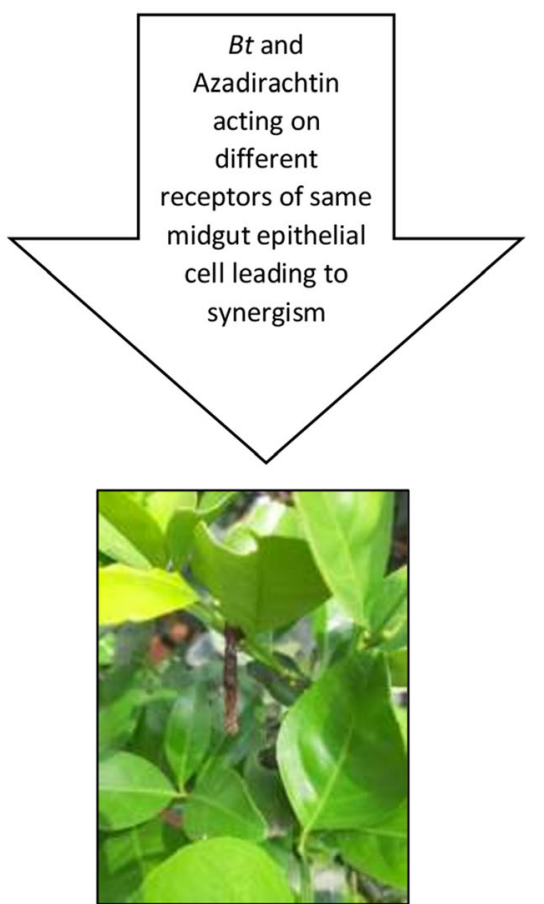

Fig. 1 Synergism of botanicals with entomopathogenic bacteria. Mummified caterpillar of citrus looper (Anacamptodes fragilaria Grossbeck) observed after application of Bt and azadirachtin combination (photo from trials conducted at CRS, Tirupati) 
2007) and $\mathrm{LC}_{20}$ of azadirachtin $0.09 \% \mathrm{EC}(6.99 \mu \mathrm{g}$ a.i./ $\mathrm{mL})$ and $B t 12.74 \% \mathrm{EC}(51.62 \mu \mathrm{g}$ a.i. $/ \mathrm{mL})$ (Abedi et al. 2014) caused 100 and $56.7 \%$ mortality of $H$. armigera, respectively, showing a high level of synergism. This is also proved by Nouri-Ganbalani et al. (2016) that $\mathrm{LC}_{50}$ concentrations of $B t(490 \mu \mathrm{g}$ a.i $/ \mathrm{mL})$ and neem $(241 \mu \mathrm{g}$ a.i $/ \mathrm{mL}$ ) when combined showed synergistic effects, whereas the $\mathrm{LC}_{30}$ combination showed additive interactions against Plodia interpunctella.

Apart from neem, there are some other botanicals with pest control properties, and one of them is palmarosa oil (Cymbopogan martini Wats.) (1\%), which showed a synergistic activity with three $B t$ products, Delfin $^{\circ}$, Spicturin ${ }^{\circ}$, and Agree ${ }^{\circ}$, against Spodoptera litura and $H$. armigera. Delfin ${ }^{\circ}$ is found to be synergistic with extracts of neem, mentha, and Prosofis juliflora but not with Spicturin ${ }^{\circ}$ and Agree ${ }^{\circ}$. This may be due to additives present in the formulation (Venkadasubramanian and David 1999). The extract of Vitex pseudonegundo (Hausskn) (Verbenaceae) was synergistic with Bt (Mancebo et al. 2002). Other botanicals, namely, Annona squamosa L., Datura stramonium L., Eucalyptus globulus (Labile), Ipomea carnea Jacq., Lantana camara L., Nicotiana tabacum L., and Pongamia pinnata (L.), all were synergistic with $B t k$, where $D$. stramonium being more synergistic with $74.7 \%$ mean larval mortality of $S$. litura (Rajguru et al. 2011). Rumex tingitanus was emphasized as a pest control agent for the first time (Mhalla et al. 2018) and was found to be larvicidal for 1st and 2nd instars and an antifeedant for 4th instar larvae of $S$. litura. In the nine different combinations of rumex extract with $B t$ strain BLB 250 (30 mg/g of diet), when tested against $S$. litura larva, seven of them showed synergism causing 100\% mortality. Mustard oil can also be used along with $B t$ crystals for achieving the synergism against Dendrolimus pini, which resulted in twofolds higher mortality (Konecka et al. 2019). Recently, carvacrol, a monoterpenoid phenol, extracted from aromatic plants (oregano) also shown synergistic effects with $B t$ against Cydia pomonella when mixed in the ratio of 1:25,000 and 1:50,000 (Bt: carvacrol) causing 1.5 and 1.9 times higher mortality, respectively. The ratio of 1:1000 and 1:2000 also showed 1.5- and 1.8-folds higher mortality of Spodoptera exigua than expected (Konecka et al. 2020). Some of the succesful synergistic interactions between botanicals and EPB are shown in Table 1.

A few studies have found that botanicals also show antagonism with $B t$ like sweet flag (Acorus calamus), Indian aloe (Aloe vera), and bracteated birthwort (Aristolochia bracteate) against S. litura (Venkadasubramanian and David 1999), and Acacia arabica have demonstrated this activity against S. litura (Rajguru et al. 2011). Halder et al. (2017) observed that Btk mixed with neem oil showed incompatible interaction in controlling Epilachna beetle, Epilachna deodecastigma.

\section{Synergism between botanicals and entomopathogenic fungi}

The compatibilities of different strains of Beauveria bassiana with different neem products were proved by many researchers (Mohan et al. 2007; Islam et al. 2010; Sahayaraj et al. 2011; Avery et al. 2013). The synergism or compatibility of botanicals, especially neem products with EPF, was proved effective against S. litura (Mohan et al. 2007), a locust Anacridum melanorhadon (Haroon et al. 2011), Bemisia tabaci (Islam and Omar 2012), mealybugs (Phenococcus soleneopsis) (Halder et al. 2013), and Epilachna deodecastigma (Halder et al. 2017). Eucalyptus extract was also proved to be viable for combining with $B$. bassiana against the wheat aphid, Sitobion avenae (Ali et al. 2018). It caused a high mortality rate and higher reduction of fecundity of the aphid $S$. avenae, than $B$. bassiana alone, $M$. anisopliae, and their combinations with neem and eucalyptus extract. Eucalyptus was thought to act on the nervous system, digestion,

Table 1 Few botanicals and entomopathogenic bacteria combinations

\begin{tabular}{|c|c|c|c|}
\hline Combination & Pest targeted & Effect & Source \\
\hline $\begin{array}{l}\text { Bt }(0.5 \%)+\text { NSKE }(5 \%) \text { (sequential application } \\
\text { within } 2 \text { days) } \\
\text { Bt }(0.25 \%)+\text { NSKE (2\%) (sequential application } \\
\text { within } 2 \text { days) }\end{array}$ & A. janata on castor & $\begin{array}{l}99.36 \% \text { decrease in larval population after } 5 \text { days of } \\
\text { sprays and showed the highest yield of } 366.53 \mathrm{~kg} / \mathrm{ha} \\
99.58 \% \text { decrease in larval population after } 5 \text { days of } \\
\text { spray with a yield of } 296 \mathrm{~kg} / \mathrm{ha}\end{array}$ & Devi et al. (1996) \\
\hline \multirow[t]{2}{*}{ Bt (Delfin) $(0.1 \%)+$ palmarosa oil $(0.5 \%)$} & S. litura & 96.29\% mortality & \multirow{2}{*}{$\begin{array}{l}\text { Venkadasubramanian } \\
\text { and David (1999) }\end{array}$} \\
\hline & H. armigera & $96.48 \%$ mortality & \\
\hline D. stramonium seed extract fortified with $B t k$ & S. litura & Highest mean larval mortality - 74.70\% & Rajguru et al. (2011) \\
\hline Btk $(0.044 \%)+$ Azadirachtin (0.031\%) & $\begin{array}{l}\text { Spilarctia obliqua (in } \\
\text { laboratory } \\
\text { conditions) }\end{array}$ & $70 \%$ mortality observed & $\begin{array}{l}\text { Bandyopadhyay et al. } \\
\text { (2014) }\end{array}$ \\
\hline $\begin{array}{l}\text { B. thuringiensis (BLB250) delta-endotoxins }+R \text {. } \\
\text { tingitanus hexane extract (RtHexF) at } 5 \mathrm{mg} \mathrm{g}^{-1}\end{array}$ & S. littoralis & $100 \%$ larval mortality of 1 st and 2 nd instar larvae & Mhalla et al. (2018) \\
\hline
\end{tabular}


growth retardation, and reproductive ability and resulted in mortality of insect which had already penetrated by $B$. bassiana (Russo et al. 2015). The extracts of Citrus vulgaris with $B$. bassiana also showed synergism ratio of 1.20 , representing a viable combination against third instar larvae of Ephestia kuehniella Zeller, where the $\mathrm{LC}_{50}$ value reduced to 92.32 from 110.98 when $B$. bassiana alone was used (Shakarami et al. 2015).

Metarhizium anisopliae was also considered to be synergistic when used in combination with botanicals viz. neem (Shoukat et al. 2016), pyrethrum (FernándezGrandon et al. 2020), and 1-chlorooctadecane (Hussain and AlJabr 2020). The combination of pyrethrum and M. anisopliae $\left(1 \times 10^{8} \mathrm{CFU} / \mathrm{mL}\right)$ reduced the Aphis fabae survival by $29.2 \mathrm{~h}$, representing their synergistic activity (Fernández-Grandon et al. 2020). 1Chlorooctadecane, a chemical obtained from the plant extracts of Albertisia papuana Becc, Syzygium cumini (L.), and Arisaema amurense Maxim, mixed with $M$. anisopliae (EBCL 02049) for controlling the date palm dust mite, Oligonychus afrasiaticus, also showed highly synergistic interaction with joint toxicity of 713 (also called co-toxicity coefficient, which is the sum of individual toxicity indices) (Hussain and AlJabr 2020).

Verticilium muscarium, another EPF $(0.16 \mathrm{mg} / \mathrm{l})$, and matrine, a quinolizidine alkaloid derived from the roots of Sophora falvescens and S. alopecuroides $(0.83 \mathrm{mg} / \mathrm{L})$, showed synergistic interaction against B. tabaci (Ali et al. 2017). The co-toxicity of these two compounds was found to be ranging 125.99 to 200.00 , showing a fair level of synergism. Another nematicidal fungus Paecilomyces lilacinus was also found to be synergistic with botanicals namely neem cake and Tagetus erecta, and when applied to soil, the combination was effective against Meloidogyne incognita, reducing the root gall index from 5 to 1 (Sundraraju and Kiruthika 2009). Each of the three EPFs, B. bassiana, $M$. anisopliae, and $L$. lecani in 1:1 combination with neem oil, was synergistic which was well recorded in terms of co-toxicity coefficients ranging from 1.003 to 1.332 against Epilachna dodecastigma and Bagrada hilaris (Halder et al. 2017). $M$. anisopliae (IIVR strain) in combination with neem oil was most effective against the Hadda beetle (E. dodecastigma), and $L$. lecanii showed a promising mixture with neem oil against the painted bug (B. hilaris) (Halder et al. 2017). Some synergistic results of EPF with botanicals are given in Table 2.

Several studies have reported that neem products also have an inhibitory effect on these EPF (Rogerio et al. 2005) by suppressing the fungal growth and spore germination (Castiglioni et al. 2003). The surprising effect of fungi $M$. anisopliae when used alone repelled the parasitoid, Aphidius colemani of Aphis fabae, but by combining with pyrethrum, it had no negative effect on the parasitoid (Fernández-Grandon et al. 2020).

\section{Synergism between botanicals and entomopathogenic virus}

Helicoverpa armigera NPV (HaNPV) was one of the most compatible entomopathogenic viruses with botanicals, neem (Kumari 2012), Tagetus patula, and Calotropis gigantean (Rabindra et al. 1994). HaNPV was incorporated in the diet of $H$. armigera along with $10 \%$ aqueous leaf extracts of T. patula and C. gigantea. These botanicals activated latent infections and caused many sublethal effects, representing synergism (Rabindra et al. 1995). Again, when the commercial neem formulation (Econeem) was used in the mixture with $\mathrm{HaNPV}$, it also showed a synergistic action by reducing the damage of

Table 2 Some botanicals and entomopathogenic fungi combinations

\begin{tabular}{|c|c|c|c|}
\hline Combination & Pest targeted & Effect & Source \\
\hline P. fumosoroseus + azadirachtin & $\begin{array}{l}\text { Whitefly } \\
\text { (laboratory } \\
\text { bioassay) }\end{array}$ & $\begin{array}{l}20 \% \text { extra nymphal mortality is observed, but azadirachtin has an } \\
\text { inhibitory effect on fungi }\end{array}$ & James (2003) \\
\hline $\begin{array}{l}\text { B. bassiana + Neemix }(4.5 \% \\
\text { azadirachtin) }\end{array}$ & $\begin{array}{l}\text { Tribolium } \\
\text { castaneum }\end{array}$ & Delays pupation but reduces mortality of pest & $\begin{array}{l}\text { Akbar et al. } \\
(2005)\end{array}$ \\
\hline $\begin{array}{l}\text { P.lilacinus + neem cake/Tagetus erecta } \\
\text { extract }\end{array}$ & $\begin{array}{l}\text { Meloidogyne } \\
\text { incognita }\end{array}$ & Reduced root gall index from 5 to 1 & $\begin{array}{l}\text { Sundraraju and } \\
\text { Kiruthika (2009) }\end{array}$ \\
\hline B. bassiana + Citrus vulgaris essential oil & $\begin{array}{l}\text { Ephestia } \\
\text { kuehniella }\end{array}$ & Highest synergism ratio of 1:20 & $\begin{array}{l}\text { Shakarami et al. } \\
\text { (2015) }\end{array}$ \\
\hline $\begin{array}{l}\text { L. muscarium }\left(0.8 \times 10^{8} \text { conidia } / \mathrm{mL}\right)+ \\
\text { matrine }(0.75 \mathrm{mg} / \mathrm{L})\end{array}$ & Bemisia tabaci & $98.31 \%$ mortality & Ali et al. (2017) \\
\hline B. bassiana + eucalyptus extract & $\begin{array}{l}\text { Sitobion } \\
\text { avenae }\end{array}$ & $\begin{array}{l}\text { Mortality rate (87\%), the lowest fecundity ( } 7 \text { nymphs per female) was } \\
\text { recorded }\end{array}$ & Ali et al. (2018) \\
\hline 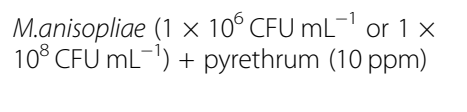 & $\begin{array}{l}\text { Bean aphid, } \\
\text { Aphis fabae }\end{array}$ & $\begin{array}{l}\text { At } 1 \times 10^{6} \mathrm{CFU} \mathrm{mL} \mathrm{mL}^{-1} \text { survival was reduced by } 29.2 \mathrm{~h} \text { through addition of } \\
\text { pyrethrum (from } 67.3 \mathrm{~h} \text { to } 35.3 \mathrm{~h} \text { ), and by } 10 \mathrm{~h} \text { at } 1 \times 10^{8} \mathrm{CFU} \mathrm{mL}^{-1}\end{array}$ & $\begin{array}{l}\text { Fernández- } \\
\text { Grandon et al. } \\
(2020)\end{array}$ \\
\hline
\end{tabular}


Table 3 Synergism of insect virus and in combination with botanicals

\begin{tabular}{|c|c|c|c|}
\hline Combination & Pest targeted & Effect & Source \\
\hline$\overline{\text { SpliNPV + Neemazal-T }}$ & S. litura & Increased the infectivity of SpliNPV by 2.9 -fold & $\begin{array}{l}\text { El-Salamouny } \\
\text { et al. (1997) }\end{array}$ \\
\hline $\begin{array}{l}\text { SINPV } 10^{4} \mathrm{PIBs} / \mathrm{mL}+\operatorname{NSKE}(0.25 \%)+ \\
\text { neem oil }(0.25 \%)\end{array}$ & S.litura & $100 \%$ mortality of all 5 stages of larvae and also adult & $\begin{array}{l}\text { Murugan et al. } \\
\text { (1999) }\end{array}$ \\
\hline SINPV + neem oil/NSKE & S. litura & Reduced $L C_{50}$ value of S/NPV by 1.05 to $1.43 / 1.03$ to 1.33 -folds & $\begin{array}{l}\text { Muralibaskaran } \\
\text { et al. (1999) }\end{array}$ \\
\hline AgseGV + neem @ 10 ppm & $\begin{array}{l}\text { A. ipsilon } \\
\text { neonate larvae }\end{array}$ & $\begin{array}{l}\text { Decrease of the } L C_{50} \text { value from } 3.59 \times 10^{7} \text { in the virus alone to } 7.11 \times \\
10^{6} \text { capsules } / \mathrm{mL}\end{array}$ & $\begin{array}{l}\text { Elnagar et al. } \\
(2004)\end{array}$ \\
\hline $\begin{array}{l}\text { HaNPV at } 10^{3} \mathrm{PIB} / \mathrm{mL}+\text { azadirachtin } \\
\text { at } 0.1 \mathrm{ppm}\end{array}$ & H. armigera & $\begin{array}{l}\mathrm{LT}_{100} \text { for } 3 \text { rd instar larvae reduced to } 72 \mathrm{~h} \text { (for NPV and AZA, it was } 168 \\
\text { and } 120 \mathrm{~h} \text {, respectively). }\end{array}$ & $\begin{array}{l}\text { Kumar et al. } \\
(2008)\end{array}$ \\
\hline $\begin{array}{l}\text { PbGV + petroleum-ether extract of } \\
\text { neem seed kernel (NSK) }\end{array}$ & P. brassicae & $\begin{array}{l}\text { Maximum reduction of } \mathrm{LC}_{50} \text { value }\left(4.39 \times 10^{2} \text { occlusion bodies [OBs] }\right. \\
\left.\mathrm{mL}^{-1}\right) \text { as compared with } \mathrm{PbGV} \text { alone }\left(1.85 \times 10^{4} \mathrm{OBs} \mathrm{mL}^{-1}\right)\end{array}$ & $\begin{array}{l}\text { Bhandari et al. } \\
\text { (2009) }\end{array}$ \\
\hline $\begin{array}{l}\text { HaNPV at } 500 \mathrm{LE} / \mathrm{ha}+\text { Neemarin } \\
(0.15 \%) \text { at } 700 \mathrm{~mL} / \mathrm{ha}\end{array}$ & $\begin{array}{l}\text { H. armigera } \\
\text { larva on tomato }\end{array}$ & $86.41 \%$ mortality of larva & Kumari (2012) \\
\hline
\end{tabular}

Helicoverpa damage in cotton (71.99\%) (Lingappa et al. 2000). The mortality of $H$. armigera was higher and $\mathrm{LT}_{100}$ for 3rd instar larvae reduced from 120 to $168 \mathrm{~h}$ to about $72 \mathrm{~h}$, when the same combination (Azadirachtin at $0.1 \%+\mathrm{NPV} 10^{3} \mathrm{PIB} / \mathrm{mL}$ ) was used (Kumar et al. 2008). Though endosulfan was found to be more synergistic and compatible with $H a \mathrm{NPV}$, from an ecological and organic agriculture point of view, neem seems to be a superior option in combination with NPV. The combinations $\mathrm{HaNPV}$ at 250 and $500 \mathrm{LE} /$ ha with Neemarin $(0.15 \%)$ at $700 \mathrm{~mL} /$ ha caused 82.39 and $86.41 \%$ mortality, respectively (Kumari 2012).

Spodoptera litura NPV (SlNPV), another promising microbial pesticide, was also found to be synergistic with neem (Nathan and Kalaivani 2006). It was observed that $\mathrm{LC}_{50}$ of $\mathrm{SlNPV}$ reduced from 1.43- to 1.05 -folds by addition of neem oil and from 1.03- to 1.33-folds by addition of NSKE. The same case was with Nathan and Kalaivani's (2006) studies where SpltNPV + azadirachtin at two different combinations, $1 \times 10^{3} \mathrm{OB}+0.25 \mathrm{ppm}$ and $1 \times 10^{6} \mathrm{OB}+0.5 \mathrm{ppm}$, were found to be more synergistic and S. litura larvae died faster in the combination.

Granulosis virus (GV) of different agricultural pests can also be combined with botanicals to get some positive interaction effects (Bhandari et al. 2009). Pieris brassicae $\mathrm{GV}(\mathrm{PbGV})$ was synergistic with botanicals in the order, NSKE > Eupatorium adenophorum $>$ Artemisia brevifolia showing that neem is best compatible with $P b G V$, and this particular combination recorded the lowest $\mathrm{LC}_{50}$ value of $1.32 \times 10^{3} \mathrm{OB} / \mathrm{mL}$ (Bhandari et al. 2009). Neem also has its positive effects on Agrotis segatum GV (AgseGV); particularly, neem oil and AgseGV combination decreased the $\mathrm{LC}_{50}$ value from $3.59 \times 10^{7}$ to $7.11 \times 10^{6}$ capsules $/ \mathrm{mL}$ diet on A. segatum (Elnagar et al. 2004). Synergistic effects of botanicals on EPV are shown in Table 3.

The findings of many research showed a positive synergism of botanicals with entomopathogenic viruses, except for Cook et al. (1997) and Elnagar et al. (2004). It was noticed that there was no enhancement of viral activity when azadirachtin was added to Lymantria dispar NPV formulation (Cook et al. 1997). The one disadvantage might be of adding azadirachtin to a viral formulation is less virus production and release into the environment (Elnagar et al. 2004).

\section{Synergism between botanicals and entomopathogenic nematodes}

Numerous studies have recorded that entomopathogenic nematodes (EPN) appear to be compatible with herbicides, nematicides (Georgis and Kaya 1998), azadirachtin (Stark 1996), and Bt (Kaya et al. 1995) and also found to be synergistic with them (Koppenhöfer and Grewal 2005). The compatibility of botanicals to EPNs was recorded by many workers, viz., Nemmarin to Steinernema masoodi, S. seemae, S. carpocapsae, S. mushtaqi (Rashid and Ali 2012), Neem suraksha to two species of Steinernema and three of Heterorhabditis (Hussaini et al. 2001), neem to $S$. feltiae (Krishnayya and Grewal 2002), neem to S. carpocapsae (Koppenhöfer and Grewal 2005; Kulkarni et al. 2009), neem and Nimor to Heterorhabditis indica (Sankar et al. 2009), neem to four nematode species, viz., S. feltiae, S. asiaticum, $H$. bacteriophora, and $H$. indica (Raheel et al. 2017). Similarly, other than neem, Pongamia glabra, $P$. pinnata, and other botanical combinations with Agropest, $B t$, Biopahar, Ozomite, to the native species of India, $S$. dharanaii (Paunikar and Kulkarni 2020). The compatibility may differ with species, strains, doses, and adjuvants used in formulations (Koppenhöfer and Grewal 2005; Javed et al. 2008; Shamseldean et al. 2013); for example, $H$. bacteriophora was found to be more sensitive to plant extracts than $H$. indica (Shamseldean et al. 2013) and $S$. feltiae was more susceptible to Margosan-O (a formulation of neem seed extract) than S. carpocapsae and S. glaseri (Javed et al. 2008). 
The different combinations of each neem product (NSKE, NeemAzal-T 5\%, Neemix 4.5\%) with S. feltiae resulted in 18 synergistic responses with NSKE, 19 with NeemAzal, and 11 with Neemix (Mahmoud 2007). The survival rates of $S$. carpocapsae combined with botanicals, viz., neem, tobacco, Derris elliptica, and Acorus calamus, was more than $94.5 \%$, but the virulence of the nematode was decreased by longer soaking periods against Galleria mellonella larva by sand column assay (Nitjarunkul et al. 2015). In contrast, NeemAzal-U on H. bacteriophora though caused significant mortality of the nematode, but virulence was not affected (Meyer et al. 2012). Some succesful synergistic interactions between botanicals and EPN are shown in Table 4.

Even though insecticides (chlorpyriphos/quinolphos at $0.04 / 0.05 \%$ ) showed the highest $H$. armigera larval reduction (41.08\%), the sequential application of $H$. indica + Pongamia pinnata (1 lakh IJs/L + 2.5\%) or their combination (1.5 lakh IJs/L $+0.75 \mathrm{~mL} / \mathrm{L})$ recorded the same level of reduction, 37.15 and 36.92, respectively (Prabhuraj et al. 2005). The emerging rate and survival of nematodes was highest in camphor oil mixed with $H$. indica or $H$. bacteriophora, followed by garlic mixture with a nematode (Shamseldean et al. 2013). The other medicinal plant extracts, for instance, Euphorbia pulcharrima $(0.714 \%)$ or garlic essential oil $(0.067 \%)$ with $S$. carpocapsae or H. bacteriphora $(500 \mathrm{IJs} / \mathrm{mL})$, increased the pest mortality, affecting development, reproduction, and lifecycle under semi-field conditions against acridid grasshopper, Heteracris littoralis (Sharaby et al. 2013).

Though there are several reports on compatibility of neem formulations with EPNs, Meyer et al. (2012) revealed the negative effects of commercial neem formulations on nematodes. The soap surfactant in commercial neem products caused $23-25 \%$ mortality of S. feltiae (Krishnayya and Grewal 2002). In contrast, a slug parasitic nematode Phasmarhabditis hermaphrodita was more susceptible (mortality) with crude neem leaf extract than the commercial formulation, NeemAzal (Petrikovszki et al. 2019), which might be due to the presence of high amounts of azadirachtin, triterpenes, viz., nimbin, nimbidine, nimbinin, azadiractol, salanin, and other such derivatives which are toxic to nematodes (Mondal and Mondal 2012). There was a variation in response of EPNs to neem-based products where it took $24 \mathrm{~h}$ for $100 \%$ mortality of Galleria larvae for $H$. indica alone, whereas along with neem, formulation (Nimor) took $48 \mathrm{~h}$ for $100 \%$ mortality, displaying the drawbacks of neem with EPNs (Sankar et al. 2009).

The infective juveniles of these EPNs were found to tolerate most of the pest control compounds for 2 to 6 $\mathrm{h}$, and in this scenario, they can be tank-mixed before use and applied, without any loss of survival and virulence (Koppenhöfer and Grewal 2005). The advantage of using these combinations is botanicals being instant in action and the nematodes may become established for offering a long-term pest reduction (Klein and Georgis 1992).

\section{Possible reasons for synergism}

Insect immune system is a major target for botanical and microbial pesticide combinations (Konecka et al. 2020). The fitness of a plant extract for combining with a microbial insecticide depends on qualitative and quantitative variations of secondary metabolites, which might affect the microbes (Ribeiro et al. 2012). It shows a clear explanation that azadirachtin can induce significant cytotoxic effects on midgut epithelium, a primary target for $B t$ toxins. It shows that the reported synergism is due to $B t$ and azadirachtin binding to different receptors on the same midgut cell, leading to an absolute damage of the midgut epithelium (Roel et al. 2010). The synergism of neem and Btk may be due to the direct effect on enzyme regulation of the insect larvae (Bandyopadhyay et al. 2014). Carvacol, a plant-based extract from many aromatic plants, acted earlier (inhibitory effect on acetylcholinesterase activity), before the rupture of midgut cells by Bt (Konecka et al. 2020). Azadirachtin causes several effects on insects, viz., growth disruption, feeding, oviposition disruption, reduction in fitness, and fecundity, thus making it more susceptible to microbial infection (Defago et al. 2011). A hypothesized reason for synergism caused by neem products on EPF that the

Table 4 Some botanicals and entomopathogenic nematode combinations

\begin{tabular}{|c|c|c|c|}
\hline Combination & Pest targeted & Effect & Source \\
\hline $\begin{array}{l}\text { P. pinnata }(0.75 \mathrm{~mL} / \mathrm{L})+H \text {. indica }(1.5 \\
\text { lakh IJs/L) }\end{array}$ & H. armigera & $36.92 \%$ larval reduction (insecticide $-41.08 \%$ ) & $\begin{array}{l}\text { Prabhuraj et al. } \\
\text { (2005) }\end{array}$ \\
\hline NSK $(0.6 \%)+$ S. feltiae (800 IJs) & $\begin{array}{l}\text { 3rd instar larvae of Bactrocera } \\
\text { zonata }\end{array}$ & $76 \%$ mortality with the highest level of synergism & Mahmoud (2007) \\
\hline $\begin{array}{l}\text { NeemAzal T 5\% (1.25\%) + S. feltiae } \\
(100 \mathrm{lJs})\end{array}$ & $\begin{array}{l}\text { 3rd instar larvae of Bactrocera } \\
\text { zonata }\end{array}$ & $100 \%$ mortality with a significant level of synergism & Mahmoud (2007) \\
\hline $\begin{array}{l}\text { M.anisopliae+ NeemAzal-T + S. } \\
\text { carpocapsae }\end{array}$ & $\begin{array}{l}\text { Frankliniella occidentalis on } \\
\text { French bean }\end{array}$ & $\begin{array}{l}32.7 \% \text { deviation from additivity and showed a high level } \\
\text { of synergism }\end{array}$ & $\begin{array}{l}\text { Otieno et al. } \\
\text { (2017) }\end{array}$ \\
\hline
\end{tabular}


growth retardation due to azadirachtin causes elongation of the inter-molt period, thus enabling more time for the fungus to attack the cuticle (Akbar et al. 2005). The compatibility of $B$. bassiana with insecticidal plant extracts is probably due to the variation in concentrations of phytoalexins, sulfurades, terpenoids, and triterpenoids (Depieri et al. 2005). Genetic variability of fungal strains is also the reason for differential compatibility to different phytosanitary products (Mohan et al. 2007). The rapid breakdown of pyrethrum and slow activation of EPF, if combined, the effect will be optimized compensating individual shortcomings (Fernández-Grandon et al. 2020). It was also observed that the reduction in Agrotis segatum larval weight is due to the antifeeding effect of neem and its effect on digestive enzyme activity and biochemical composition in the midgut, prior to the attack by a virus (Elnagar et al. 2004). The sublethal concentrations of individual components used in virus combinations do not cause the pest mortality directly but may induce changes in physiological behavioral activity (pest fitness) due to the combined botanical effect as they mainly act as stressors and show latent infection activators of EPV (Rabindra et al. 1995). Thus, the botanicals alter the pathophysiology of the insect during the subsequent viral attack (Nathan and Kalaivani 2006). The explanatory reason for synergism between botanicals and EPNs is less studied, and one such case is azadirachtin within $48 \mathrm{~h}$ of application completely stopped the development of larvae (Otiorhynchus sulcatus), showing growth disruptive properties (Gaffney et al. 2005), and this may be the cause of attack by EPNs (Sankar et al. 2009).

\section{Conclusion}

In most of the reviewed cases, the combinations of botanicals with the entomopathogenic agents showed certain levels of regulations of pests' populations. The combinations can create a new outstanding commercial bioinsecticide formulation giving boost to organic farmers, and the efficacy of these bio-combi products is especially to overcome the individual shortcomings of each product. Still, there is a dire need and scope for further studies on the effect on the behavior of pests, the importance of application technique, and the role of application timing for these botanical biopesticide combinations.

\section{Abbreviations}

Bt: Bacillus thuringiensis; $L_{5}$ : Lethal concentration for $50 \%$ of population; NSKE: Neem seed kernel extract; PIB: Poly inclusion bodies

\section{Authors' contributions}

Conceptualization by DSR, writing - original draft preparation by DSR and NMC, writing - review and editing by both authors. All authors have read and approved the final manuscript.

\section{Funding}

Not applicable

Availability of data and materials

Data sharing is not applicable to this article as no datasets were generated or analyzed during the current study.

\section{Ethics approval and consent to participate}

Not applicable

Consent for publication

Not applicable

\section{Competing interests}

The authors declare that they have no competing interests.

\section{Author details}

${ }^{1}$ AICRP on Fruits, Citrus Research Station, Drysrhu, Tirupati, Andhra Pradesh 517501, India. ${ }^{2}$ CSKHPKV, Palampur, Himachal Pradesh 176062, India.

Received: 29 August 2020 Accepted: 8 January 2021

Published online: 25 January 2021

\section{References}

Abedi Z, Saber M, Vojoudi S, Mahdavi V, Parsaeyan E (2014) Acute, sublethal and combination effects of azadirachtin and Bacillus thuringiensis on the cotton bollworm, Helicoverpa armigera. J Insect Sci 14:30

Adams BJ, Nguyen KB (2002) Taxonomy and systematic. In: Gaugler A (ed) Entomopathogenic nematology. CABI Publishing, Wallingford, pp 1-33

Akbar W, Lord CJ, Nechols JR, Loughin TM (2005) Efficacy of Beauveria bassiana for red flour beetle when applied with plant essential oil or in mineral oil and organosilicone carriers. J Econ Entomol 98:683-688

Ali S, Faroogi MA, Sajjad A, Ullah MI, Qureshi AK, Siddique B, Waheed W, Sarfraz M, Asghar A (2018) Compatibility of entomopathogenic fungi and botanical extracts against the wheat aphid, Sitobion avenae (Fab.) (Hemiptera: Aphididae). Egypt J Biol Pest Control 28:97. https://doi.org/10.1186/s41938018-0101-9

Ali S, Zhang C, Wang Z, Wang XM, Wu JH, Cuthbertson AGS, Shao Z, Qiu BL (2017) Toxicological and biochemical basis of synergism between the entomopathogenic fungus Lecanicillium muscarium and the insecticide matrine against Bemisia tabaci (Gennadius). Sci Rep 7:46558. https://doi.org/ 10.1038/srep46558

Alves SB, Lopes RB, Vieira AS, Tamai MA (2008) Fungos entomopatogênicosusados no controle de pragasna América Latina. In: Alves SB, Lopes RB (eds) Controle Microbiano de Pragasna América Latina: avanços e desafios, vol 2008, 1st edn. FEALQ, Piracicaba

Avery PB, Pick DA, Aristizábal LF, Kerrigan J, Powell CA, Rogers ME, Steven P (2013) Arthurs compatibility of Isaria fumosorosea (Hypocreales: Cordycipitaceae) blastospores with agricultural chemicals used for management of the Asian citrus psyllid, Diaphorina citri (Hemiptera: Liviidae). Insects 4:694-711. https://doi.org/10.3390/insects4040694

Bandyopadhyay S, Gotyal BS, Satpathy S, Selvaraj K, Tripathi AN, Ali N (2014) Synergistic effect of azadirachtin and Bacillus thuringiensis against Bihar hairy caterpillar, Spilarctica obliqua Walker. Biopestic Int 10(1):71-76

Bhandari K, Sood P, Mehta PK, Choudhary A, Chandra S (2009) Prabhakar Effect of botanical extracts on the biological activity of granulosis virus against Pieris brassicae. Phytoparasitica. https://doi.org/10.1007/s12600-009-0047-2

Bravo A, Likitvivatanavong S, Gill SS, Soberón M (2011) Bacillus thuringiensis: a story of a successful bioinsecticide. Insect Biochem Mol Biol 41:423-431

Castiglioni E, Vendramin JD, Alves SB (2003) Compatibility between Beauveria bassiana and Metarhizium anisopliae with Nimkol-L in the control of Heterotermes tenuis Man. Integr Plagas Agroecol 69:38-44

Cook SP, Webb RE, Thorbe KW, Podgwaite JD, Whim GB (1997) Field examination of the influence of azadirachtin on gypsy moth (Lepidoptera: Lymantriidae) nuclear polyhedrosis virus. J Econ Entomol 90(5):1267-1272 
Defago MT, Dumon A, Avalos DS, Palacios SM, Valladares G (2011) Effect of Melia azadirach extract on Cotesia Ayerza, parasitoid of the alfalfa defoliator Colias lesbian. Biol Control 57:75-78

Depieri RA, Martinez SS, Jr Menezes AO (2005) Compatibility of the fungus Beauveria bassiana (Bals.) Vuill. (Deuteromycetes) with extracts of neem seeds and leaves and the emulsible oil. Neotro. Entomol 34:601-606

Devi PSV, Prasad YG, Rajeswari B (1996) Effect of Bacillus thuringiensis var. kurstaki and neem on castor defoliators- Achaea Janata (Linnaeus) and Spodoptera litura (Fabricus). J Biol Control 10:67-71

El-Salamouny S, Huber J, Elnagar S, El-Sheikh MAK (1997) Increasing the susceptibility to nuclear polyhedrosis viruses by synergistic additives. In: Proceeding of a Symposium, Unic. of Warwick, Coventry, UK, 16-18 April, p 289-292

Elnagar S, El-Shikh MAK, El-Salamouny S, Amin AA, Khattab M (2004) Simultaneous effect of certain botanicals activity on the relative pathogenicity of (Agsegv) on Agrotis ipsilon. Belt-wide cotton conferences, San Antonio, 5-9 January, 2004

Etheimine MO, Kane CMH, Ely SO, Barry A, Mohamed SO, Babah MAO et al (2013) Storability of five new formulations of Green Muscle ${ }^{\circledast}$ (Metarhizium acridum) under ambient and low temperatures: evaluation of conidial viability and virulence against desert locust nymphs. Int J Trop Insect Sci 33(3):195-201

Fernández-Grandon GM, Harte SJ, Ewany J, Bray D, Philip C (2020) Stevenson additive effect of botanical insecticide and entomopathogenic fungi on pest mortality and the behavioral response of its natural enemy. Plants 9:173. https://doi.org/10.3390/plants9020173

Gaffney MT, Maher M, Purvis G (2005) Efficacy of Metarhizium anisopliae and neem seed kernel for the control of Otiorhynchus sulcatus in nursery stock containers. In: Proceedings of Agricultural Research Forum: Tullamore, p 34.

Georgis R, Kaya HK (1998) Formulation of entomopathogenic nematodes. In: Burges HD (ed) Formulation of microbial biopesticides: beneficial microorganisms, nematodes and seed treatments. The Netherlands, Kluwer, pp 289-308

Halder J, Kushwaha D, Rai AB, Singh A, Singh B (2017) Potential of entomopathogens and neem oil against two emerging insect pests of vegetables. Indian J Agric Sci 87(2):220-224

Halder J, Rai AB, Kodandaram MH (2013) Compatibility of neem oil and different entomopathogens for the management of major vegetable sucking pests. Natl Acad Sci Lett 36:19-25

Haroon WM, Pages C, Vassal JM, Abdalla AM, Luong-Skovmand MH, Lecoq M (2011) Laboratory and field investigation of a mixture of Metarhizium acridum and neem seed oil against the tree locust Anacridium melanorhodon (Orthoptera: Acrididae). Biocontrol Sci Tech 21:353-366

Hussain A, AlJabr AM (2020) Potential synergy between spores of Metarhizium anisopliae and plant secondary metabolite, 1-chlorooctadecane for effective natural acaricide development. Molecules 25:1900. https://doi.org/10.3390/ molecules 25081900

Hussaini S, Kavita S, Satya J, Hussain A (2001) Tolerance of some indigenous entomopathogenic nematodes isolates to pesticides and their effect on multiplication. Curr Nematol 12(1):29-34

Islam MT, Castle SJ, Shunxiang R (2010) Compatibility of the insect pathogenic fungus, Beauveria bassiana with neem against sweet potato whitefly, Bemisia tabaci, on eggplant. Entomol Exp Appl 134:28-34

Islam MT, Omar DB (2012) Combined effect of Beauveria bassiana with neem on virulence of insect in case of two application approaches. J Anim Plant Sci 22(1):77-82

Isman MB (2006) Botanical insecticides, deterrents, and repellents in modern agriculture and an increasingly regulated world. Annu Rev Entomol 51:45-66

James RR (2003) Combining azadirachtin and Paecilomyces fumosoroseus (Deuteromycotina: Hyphomycetes) to control Bemisia argentifolii (Homoptera: Aleyrodidae). J Econ Entomol 96(1):25-30

Javed N, Gowen SR, El-Hassan SA, Inam-ul-Haq M, Shahina F, Pembroke B (2008) Efficacy of neem (Azadirachta indica) formulations on biology of root-knot nematodes (Meloidogyne javanica) on tomato. Crop Prot 27:36-43

Kaya HK, Burlando TM, Choo HY (1995) Integration of entomopathogenic nematodes with Bacillus thuringiensis or pesticidal soap for control of insect pests. Biol Control 5:432-441

Klein MA, Georgis R (1992) Persistence of control of Japanese beetle (Coleoptera: Scarabaeidae) larvae with Steinernematid and Heterorhabditid nematodes. J Econ Entomol 85:727-730

Konecka E, Kaznowski A, Grzesiek W, Nowicki P, Czarniewska E, Baranek J (2020) Synergistic interaction between carvacrol and Bacillus thuringiensis crystalline proteins against Cydia pomonella and Spodoptera exigua. Biocontrol 65:447-460
Konecka E, Kaznowski A, Tomkowiak D (2019) Insecticidal activity of mixtures of Bacillus thuringiensis crystals with plant oils of Sinapis alba and Azadirachta indica. Ann Appl Biol 174(3):364-371

Koppenhöfer AM, Grewal PS (2005) Compatibility and interactions with agrochemicals and other biocontrol agents. In: Nematodes as biocontrol agents. CABI, Wallingford, pp 363-381

Koul O, Walia S (2009) Comparing impacts of plant extracts and pure allelochemicals and implications for pest control. CAB Rev 4(49):1-30 Available via CABI. http://www.cabi.org/cabreview. Accessed 15 Aug 2020

Krishnayya PV, Grewal PS (2002) Effect of neem and selected fungicides on viability and virulence of Entomopathogenic nematode Steinernema feltiae. Biocontrol Sci Tech 12:259-266

Kulkarni N, Mishra VK, Paunikar SD (2017) Infectivity of native populations ofentomopathogenic nematodes against teak defoliators. J Entomol Zool Stud 5(6):639-643

Kulkarni N, Paunikar S, Hussaini SS (2009) Tolerance of Entomopathogenic nematodes, Heterorhabitis indica to some common insecticides useful for developing IPM strategy against forest insect pests. In: 5 th International Conference on Biopesticides: Stakeholders Perspective (ICOBV 2009), New Delhi.

Kumar NS, Murugan K, Zhang W (2008) Additive interaction of Helicoverpa armigera nucleopolyhedrovirus and azadirachtin. BioControl 53:869-880

Kumari V (2012) Efficacy of an Ecosafe Helicoverpa armigera nuclear polyhedrosis virus ( $\mathrm{Ha} \mathrm{Npv}$ ) alone and in combination with insecticides against $H$. armigera on tomato crop. Int Arch Appl Sci Technol 3(3):29-32

Lingappa S, Rajendra H, Udikeri SS (2000) Evaluation of Econeem with microbial insecticides against Helicoverpa armigera (Hubner) in cotton. Karnataka J Agric Sci 13:597-600

Lucia A, Juan LW, Zerba EN, Harrand L, Marcó M, Masuh HM (2012) Validation of models to estimate the fumigant and larvicidal activity of eucalyptus essential oils against Aedes aegypti (Diptera: Culicidae). Parasitol Res 110(5): 167-186

Lv J, Wilson LT, Beuzelin JM, White WH, Reagan TE, Way MO (2011) Impact of Cotesia flavipes (Hymenoptera: Braconidae) as an augmentative biocontrol agent for the sugarcane borer (Lepidoptera: Crambidae) on rice. Biol Control 56(2):159-169

Mahmoud FM (2007) Combining the botanical insecticides NSK extract, Neem Azal T 5\%, Neemix 4.5\% and the entomopathogenic nematode Steinernema feltiae cross N 33 to control the peach fruit fly, Bactrocera zonata (Saunders). Plant Prot Sci 43(1):19-25

Mancebo F, Hilje L, Mora GA, Salazar R (2002) Biological activity of two neem (Azadirachta indica A. Jus., Meliaceae) products on Hypsipyla grandella (Lepidoptera: Pyralidae) larvae. Crop Prot 21:107-112

Mann RS, Kaufman PE (2012) Natural product pesticides: their development, delivery and use against insect vectors. Min Rev Org Chem 9:185-202

Meyer J, Ebssa L, Poehling H-M (2012) Survival, host infection and reproduction of entomopathogenic and plant-parasitic nematodes: Heterorhabditis bacteriophora and Meloidogyne incognita. J Plant Dis Protect 119(4):142-151

Mhalla D, Farhat-Touzri DB, Tounsi S, Trigui M (2018) Combinational Effect of Rumex tingitanus (Polygonaceae) hexane extract and Bacillus thuringiensis endotoxin against Spodoptera littoralis (Lepidoptera: Noctuidae). Hindawi BioMed Res Int 3895834:7. https://doi.org/10.1155/2018/3895834

Mohan MC, Reddy NP, Devi UK, Kongara R, Sharma HC (2007) Growth and insect assays of Beauveria bassiana with neem to test their compatibility and synergism. Biocont Sci Technol 17(10):1059-1069

Mondal D, Mondal T (2012) A review of efficacy of Azadirachta indica A. Juss based biopesticides: an Indian perspective. Res J Recent Sci 1:94-99

Morgan ED (2009) Azadirachtin, a scientific gold mine. Bioorg Med Chem 17: 4096-4105

Muralibaskaran RK, Venugopal NS, Mahadevan NR (1999) Effect of certain botanicals on biological activity of nuclear polyhedrosis virus of tobacco caterpillar (Spodoptera litura). Indian J Agric Sci 69:224-226

Murugan K, Shivaramakrishnan S, Kumar NS, Jeyabalan D, Nathan SS (1999) Potentiating effects of neem on NPV treatment of Spodoptera litura Fab. Insect Sci Appl 19:229-235

Nathan SS, Kalaivani K (2006) Combined effects of azadirachtin and Nucleopolyhedrovirus (SpltNPV) on Spodoptera litura Fabricius (Lepidoptera: Noctuidae). Biol Control 39:96-104

Nitjarunkul A, Mangtab S, Noosidum A (2015) Effect of botanical insecticides on survival and virulence of Steinernema carpocapsae (Weiser). Proceeding of the 53rd Kasetsart University Annual Conference, Bangkok, pp 122-129 
Nouri-Ganbalani G, Borzoui E, Abdolmaleki A, Abedi Z, Kamita SG (2016) Individual and combined effects of Bacillus thuringiensis and Azadirachtin on Ploidia interpunctella Hubner (Lepidopetra: Pyralidae). J Insect Sci 16(1):95 1-8

Otieno JA, Pallmann P, Poehling HM (2017) Additive and Synergistic interactions amongst Orius laevigatus (Heteroptera: Anthocoridae), entomopathogens and azadirachtin for controlling western flower thrips (Thysanoptera: Thripidae). Biocontrol 62:85-95

Paunikar S, Kulkarni N (2019a) Evaluation of new species of entomopathogenic nematode, Steinernema dharanaii (TFRIEPN-15) against Bamboo leaf roller, Crypsipyta coclesalis Walker (Lepidoptera: Pyralidae) in the laboratory. Indian Forester 145(8):767-773

Paunikar S, Kulkarni N (2019b) Bioefficacy and progeny production of native newto-science species of entomopathogenic nematodes, Steinernema dharanaii (TFRIEPN-15) against forest insect pest, Albizia defoliator, Spirama retorta Cramer (Lepidoptera: Noctuidae). Res J Agric For Sci 7(4):10-16

Paunikar S, Kulkarni N (2019c) Efficacy of entomopathogenic nematode, Steinernema dharanaii (TFRIEPN-15) against termites Odonto termesobesus (Isoptera: Termitidae) in the laboratory. Indian J For 42(4):105-108

Paunikar S, Kulkarni N (2020) Compatibility of new species of entomopathogenic nematode, Steinernema dharanaii Kulkarni et al., 2012 (Nematoda: Rhabditida: Steinernematidae) from India with some modern biopesticides. Int J Environ Agric Biotechnol 5(3):553-565. https://doi.org/10.22161/ijeab.53.8

Petrikovszki R, Doshi P, Turóczi G, Tóth F, Nagy P (2019) Investigating the sideeffects of neem-derived pesticides on commercial entomopathogenic and slug-parasitic nematode products under laboratory conditions. Renáta Plants 8:281. https://doi.org/10.3390/plants8080281

Phukon M, Sarma I, Borgohain R, Sarma B, Goswami J (2014) Efficacy of Metarhizium anisopliae, Beauveria bassiana and neem oil against tomato fruit borer, Helicoverpa armigera under field condition. Asian J Bio Sci 9(2):151-155

Prabhuraj A, Patil BV, Girish KS, Shivaleela (2005) Field evaluation of an insect parasitic nematode, Heterorhabditis indica (RCR) in combination with other entomopathogens and botanicals against chickpea pod borer, Helicoverpa armigera (Hiibner). J Biol Control 19(1):59-64

Rabindra RJ, Nambi SA, Araj SJ (1994) Evaluation of certain botanicals as stressors of nuclear polyhedrosis virus in larvae of Helicoverpa armigera. J Biol Control 8(2):129-130

Rabindra RJ, Nambi SA, Araj SJ (1995) Evaluation of certain botanicals as stressors of nuclear polyhedrosis virus in larvae of Helicoverpa armigera. J. Biol.Control 8(2):129-130

Raheel M, Javed N, Khan SA, Ahmed S (2017) Exploiting the biocontrol potentia of entomopathogenic nematodes in combination with chemical against greater wax moth (Galleria mellonella). J Anim Plant Sci 27(3):877-881

Rajguru M, Sharma AN, Banerjee S (2011) Assessment of plant extracts fortified with Bacillus thuringiensis (Bacillales: Bacillaceae) for management of Spodoptera litura (lepidoptera: Noctuidae). Int J Trop Insect Sci 31:92-97

Rashid P, Ali SS (2012) Compatibility of entomopathogenic nematodes (Nematoda: Rhabditida) with pesticides and their infectivity against lepidopteron insect pest. Trends Biosci 5(1):71-73

Reddy KRK, Kumar PD, Reddy KRN (2013) Entomopathogenic fungi: a potential bioinsectcide. Kavaka 41:23-32

Ribeiro LP, Blume E, Bogorni PC, Dequech STB, Brand SC, Junges E (2012) Compatibility of Beauveria bassiana commercial isolate with botanical insecticides utilized in organic crops in southern Brazil. Biol. Agric. Hortic 28 223-240

Roel RA, Dourado DM, Matias R, Porto KRA, Bednaski AV, da Costa RB (2010) The effect of sub-lethal doses of Azadirachta indica (Meliaceae) oil on the midgut of Spodoptera frugiperda (Lepidoptera, Noctuidae). Rev Bras Entomol 54:505-510

Rogerio A, Depieri S, Martinez S, Menezes AO (2005) Compatibility of the fungus Beauveria Bassiana (Bals.) Vuill. (Deuteromycetes) with extracts of neem seeds and leaves and the emulsible oil. Neotrop Entomol 34(4):601-606

Rosell G, Quero C, Coll J (2008) Biorational insecticides in pest management. J Pestic Sci 33:103-121

Russo S, Cabrera N, Chludil H, Yaber-Grass M, Leicach H (2015) Insecticidal activity of young and mature leaves essential oil from Eucalyptus globulus Labill. Against Tribolium confusum Jacquelin du Val (Coleoptera: Tenebrionidae). Chil J Agri Res 75(3):375-379

Sahayaraj K, Namasivayam SKR, Rathi JM (2011) Compatibility of entomopathogenic fungi with extracts of plants and commercial botanicals. Afr J Biotechnol 10:933-938

Sankar M, Sethuraman V, Palaniyandi M, Prasad JS (2009) Entomopathogenic nematodes, Heterorhabditis indica and its compatibility with other biopesticides on the greater wax moth, (Galleria mellonella L.). Indian J Sci Technol 2(1):57-62

Shakarami J, Eftekharifar R, Latifian M, Jafari S (2015) Printed in India Insecticidal activity and synergistic effect of Beauvaria bassiana (Bals.) Vuill. and three botanical compounds against third instar larvae of Ephestia kuehniella Zeller. Res Crops 16(2):296-303

Shamseldean MM, Sharaby AF, Gesraha MA, Montasser SA, Ibrahim SA (2013) Utilization of entomopathogenic nematodes combined with plant extracts and plant essential oils against grasshopper, Heteracris littoralis. J Basic Appl Sci Res 3(11):289-294

Sharaby A, Gesraha MA, Montasser SA, Mahmoud YA, Ibrahim SA (2013) Combined effect of some bio-agents against the grasshopper, Hetiracris littoralis under semi-field condition. IOSR J Agric Vet Sci 3(5):29-37

Sharifi S, Karimi J, Hosseini M, Rezapanah M (2014) Efficacy of two entomopathogenic nematode species as potential biocontrol agents against the rosaceae long horned beetle, Osphranteria coerulescens, under laboratory conditions. Nematology 16:729-737

Shoukat RF, Freed S, Ahmad KW (2016) Evaluation of binary mixtures of entomogenous fungi and botanicals on biological parameters of Culex pipiens (Diptera: Culicidae) under laboratory and field conditions. Int J Mosq Res 3:17-24

Shubakov A, Kucheryavykh PS (2004) Chitinolytic activity of filamentous fungi. Appl Biochem Microbiol 40(5):445-447

Singh G, Rup PJ, Koul O (2007) Acute, sublethal and combination effects of azadirachtin and Bacillus thuringiensis toxins on Helicoverpa armigera (Lepidoptera: Noctuidae) larvae. Bull Entomol Res 97(4):351-357

Srivastava CN, Lalit M, Sharma P, Prejwlita M (2011) A review on prospective of synergistic approach in insect pest management. J Entomol Res 35:255-266

Stark JD (1996) Entomopathogenic nematodes (Rhabditida: Steinernematidae): toxicity of Neem. J Econ Entomol 89:68-73

Sundraraju P, Kiruthika P (2009) Effect of bio-control agent, Paecilomyces lilacinus along with neemcake and botanicals for the management of Meloidogyne incognita on banana. Indian J Nematol 39(2):201-206

Thacker JRM (2002) An introduction to arthropod pest control. Cambridge University Press, Cambridge

Togbe CE, Zannou E, Gbehounou G, Kossou, Huis AV (2014) BBC: Biological based combinations- a concept way forward in sustainable pest management. Int J Trop Insect Sci 34:248-259

Trisyono A, Whalon ME (1999) Toxicity of neem applied alone and in combinations with Bacillus thuringiensis to Colorado potato beetle (Coleoptera: Chrysomelidae). J Econ Entomol 92(6):1281-1285

Venkadasubramanian V, David PMM (1999) Insecticidal toxicity of commercial Bacillus thuringiensis (Berliner) products in combination with botanicals to Spodoptera litura (Fabricius) and Helicoverpa armigera (Hubner). J Biol Control 13:85-92

Wongtang S, Nawanich S (2001) Some insecticidal plant extracts for controlling maize weevil, Sitophilus zeamais Motschulsky Coleoptera: Curculionidae. Kasetsart J 35:259-270

Zare R, Gams W (2001) A revision of Verticillium section Prostrata IV. The genera Lecanicillium and Simplicillium gen nov. Nova Hedwigia 73(1-2):1-50

\section{Publisher's Note}

Springer Nature remains neutral with regard to jurisdictional claims in published maps and institutional affiliations. 